\title{
Prospects for the Development of Digital Economy in the Region
}

\author{
Study on the Example of the Voronezh Region
}

\author{
Irina Bejnar \\ Voronezh State Technical University \\ Voronezh, Russia \\ E-mail: beinar@mail.ru \\ Tatiana Narolina \\ Voronezh State Technical University" \\ Voronezh, Russia \\ E-mail: narolina@inbox.ru
}

\author{
Olga Myasnyankina \\ Voronezh State Technical University \\ Voronezh, Russia \\ E-mail: myasnolga@yandex.ru \\ Marina Samogorodskaya \\ Voronezh State Technical University" \\ Voronezh, Russia \\ E-mail: marta17@yandex.ru
}

\begin{abstract}
The upcoming digital transformation of the Russian economy requires the subjects of the Russian Federation to create comprehensive conditions for the widespread introduction of information and communication technologies in order to ensure effective interaction of the economic, social and cultural spheres. Based on the author's methodology for calculating the Digital Russia index, the digitalization level of the subjects of the Central Black Earth region is investigated. Based on the results of the assessment, an in-depth analysis of the digital development level of the Voronezh region was carried out; the specificity of the regional potential was identified in terms of prospects for overcoming the backlog, for which the formation of an IT cluster was proposed. A number of measures are proposed to eliminate imbalances in the ratio of the levels of the Digital Russia subindices in the Voronezh region, which can be implemented within the framework of the information technology cluster.
\end{abstract}

Keywords-digital economy; digitalization process; innovation process; IT cluster; information and communication technologies

\section{INTRODUCTION}

Global changes in the technological, financial, economic and information spheres have an inevitable impact on the development of both national and regional economic systems. The effective interaction of these spheres of the world economy is currently determining the leading trend in digital industrialization - the so-called "Industry 4.0" concept, in which it is planned to create large-scale conditions for ensuring such interaction based on the use of information and communication technologies (ICT).

N Decree of the President of the Russian Federation dated 09.05.2017 No. 203 "Strategies for the Development of the Information Society of the Russian Federation for 2017-2030", the determining attribute of the digital economy is the improvement of business performance: "The digital economy is an economic activity in which the key factor in production is data in digital form, the processing of large volumes and the use of analysis results which compared with traditional forms of management can significantly increase the efficiency of various types of production, technologies, equipment, storage, sale, delivery of goods and services "[1]. Thus, within the framework of the new concept, it is supposed to orient the domestic economy on the use of innovative models for organizing business processes based on promising ICTs [2]. In this context, it is very relevant to conduct relevant studies of digitalization processes in the constituent entities of the Russian Federation with the aim of developing a long-term and comprehensive development strategy and integration into the national - and then the world - information space.

\section{ANALYSis OF THE Digitalization LEVEL OF} SubJeCts OF THE CENTRAL Black EARTh REgION AND THE PROSPECTS FOR THE DEVELOPMENT OF DIGITALIZATION IN THE VORONEZH REGION

It is obvious that a systematic digital transformation of the regions cannot occur without determining the basic level of readiness of individual subjects for the perception of innovative ICT. An example of a timely developed algorithm for assessing complex digitalization processes in Russian regions is the author's methodology of the Center for Financial Innovations and Cashless Economics of the Moscow School of Management SKOLKOVO [3], based on expert judgment and calculation of quantitative indicators. The analysis of regional metadata arrays from open sources in it is carried out according to a number of mandatory criteria for the development of ICT:

- target orientation

- the presence of innovative initiatives,

- specification of the implemented initiative activities, 
- compliance with state and regional development strategies,

- the presence of a positive social effect,

- providing benefits for regional business,

- the publicity of the digitalization process.
Initiatives that meet the above criteria are systematized according to seven groups of sub-indices, on the basis of which, in turn, the formation of the Digital Russia index itself is carried out (on a 100-point scale). "Table I" presents the digitalization indices for the regions of the Central Black Earth region obtained as a result of monitoring during 2017 2018.

TABLE I. Changes in the Digital Russia IndeX For 2017-2018 (IN the Regions of the CENTRAL Black Earth Region)

\begin{tabular}{|l|l|l|l|l|}
\hline Subject of the CEC & \multicolumn{1}{|c|}{$\mathbf{2 0 1 7}$} & $\mathbf{2 0 1 8}$ & Growth rate & Place of the region among the subjects of the Russian Federation \\
\hline Lipetsk region & 62,59 & 72,37 & 1,16 & 11 \\
\hline Belgorod region & 64,51 & 73,09 & 1,13 & 14 \\
\hline Voronezh region & 61,57 & 70,93 & 1,15 & 20 \\
\hline Kursk region & 60,12 & 68,70 & 1,14 & 24 \\
\hline Tambov region & 44,16 & 55,86 & 1,26 & 48 \\
\hline
\end{tabular}

More clearly dynamic changes in the index values are presented in "Fig. 1".

Based on a number of studies the authors formulated the basic conditions conducive to the potential success of the region in the process of digital transformation:

- provision with specialized personnel on the basis of professional educational centers;

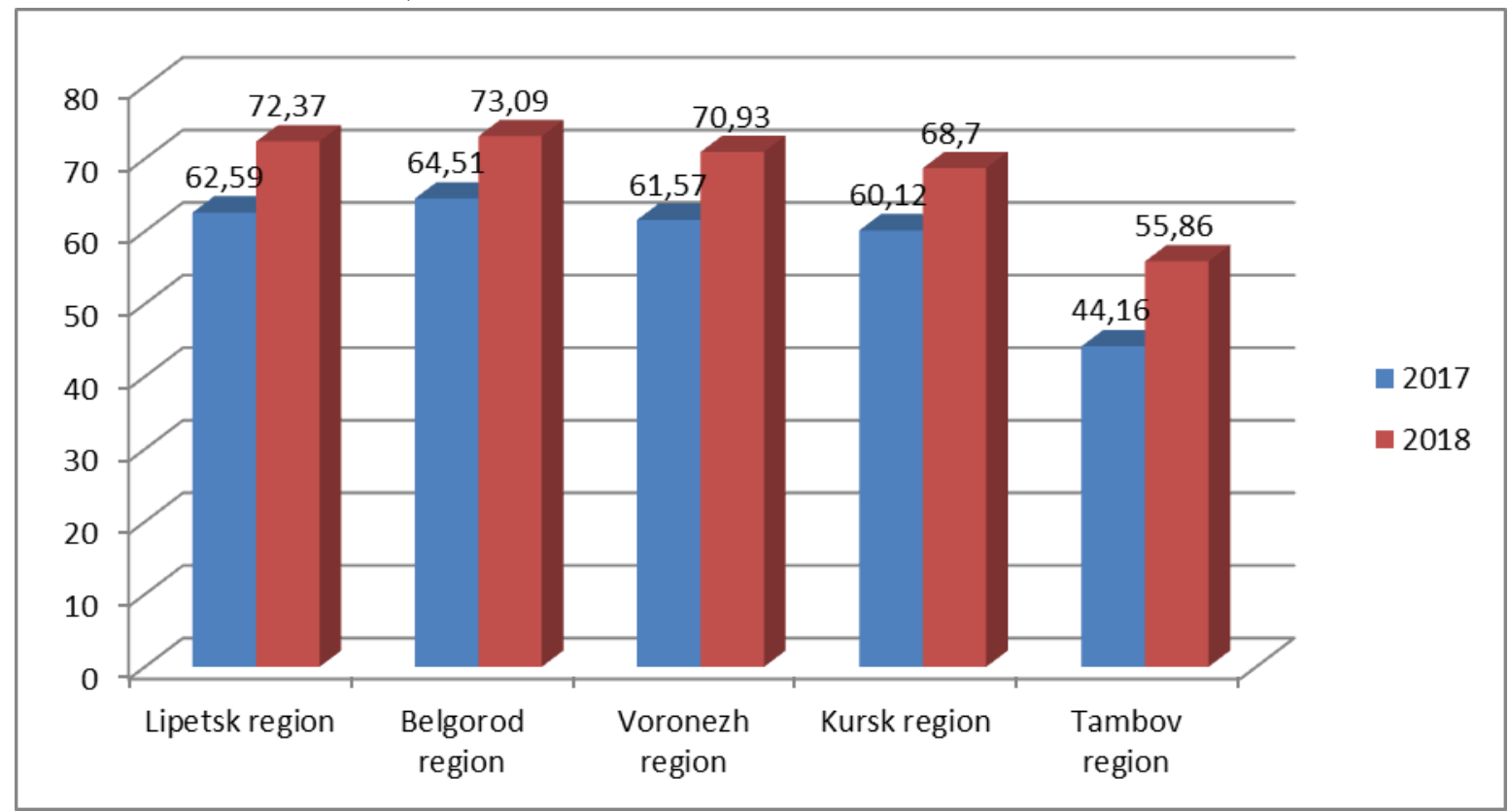

Fig. 1. Dynamics of the Digital Russia Index by the Central Black Sea Region for 2017-2018.

Thus, the leading positions of the Lipetsk and Belgorod regions identified during the monitoring in terms of the absolute value of the index are completely correlated with the characteristics that determine various aspects of their development, namely, the presence of a significant scientific and production base in the first subject of the Central Chernozem Region and high indicators of socio-economic development in the second. Of course, the selected conditions do not provide digital development automatically - an example of which is precisely the Kursk region, where the scientific and production base is no less significant than in Lipetsk, but the effectiveness of its use is clearly lower.
- $\quad$ strong research and production base;

- high rates of socio-economic development;

- high investment attractiveness.
The Tambov region, in turn, does not possess sufficiently any of the above characteristics, however, their absence is compensated by the attention of municipal administrations to the problem and, as a result, the high growth rates.

Voronezh region occupies a leading position in the Black Earth region and surpasses neighboring regions in terms of GDP, territory and population. However, it is almost two points behind the leader of the Central Digital Development Center in the Digital Russia index of the Belgorod Region, despite the industrial nature of the activity, undeniably high research potential and the availability of highly qualified 
- the formation of a regulatory framework,

personnel. In addition, the Voronezh region in 2018 is characterized by high investment activity [4] (included in the top 10 constituent entities of the Russian Federation in the National Investment Climate Rating [5]).

In order to determine the directions of increasing the digitalization level and the necessary measures of regional economic policy, the study was supplemented by an analysis of seven groups of indicators that determine the formation of the final Digital Russia index ("Table II"). Subindexes cover the main directions of the implementation of regional ICT initiatives:
- provision of professional staff,

- development of research competencies,

- creation of information infrastructure,

- ensuring information security,

- socio-economic effects.

TABLE II. The VAlues of THE COMPONENTS OF THE Digital Russia INDEX By AREAS OF THE CENTRAL BLACK EARTh REGION IN 2018

\begin{tabular}{|c|c|c|c|c|c|c|c|c|c|}
\hline No & $\begin{array}{c}\text { Subjects of } \\
\text { the Central } \\
\text { Black Earth } \\
\text { Region }\end{array}$ & $\begin{array}{c}\text { Regulatory } \\
\text { Regulation } \\
\text { and } \\
\text { Administrative } \\
\text { Indicators of } \\
\text { Digitalization }\end{array}$ & $\begin{array}{l}\text { Specialized } \\
\text { Personnel } \\
\text { and } \\
\text { training } \\
\text { programs }\end{array}$ & $\begin{array}{l}\text { Presence and } \\
\text { formation of } \\
\text { research } \\
\text { competencies } \\
\text { and } \\
\text { technological } \\
\text { groundwork }\end{array}$ & $\begin{array}{l}\text { Information } \\
\text { infrastructure }\end{array}$ & $\begin{array}{l}\text { Information } \\
\text { security }\end{array}$ & $\begin{array}{l}\text { Economic } \\
\text { indicators of } \\
\text { digitalization }\end{array}$ & $\begin{array}{c}\text { Social effect } \\
\text { of the } \\
\text { introduction } \\
\text { of } \\
\text { digitalization }\end{array}$ & Index \\
\hline 1 & $\begin{array}{l}\text { Belgorod } \\
\text { Region }\end{array}$ & 70,06 & 72,50 & 73,59 & 71,98 & 72,05 & 75,72 & 77,52 & 73,09 \\
\hline 2 & Lipetsk region & 67,53 & 75,00 & 73,18 & 73,15 & 73,88 & 65,32 & 73,37 & 72,37 \\
\hline 3 & $\begin{array}{l}\text { Voronezh } \\
\text { region } \\
\end{array}$ & 69,61 & 73,84 & 66,17 & 74,71 & 66,68 & 69,95 & 69,78 & 70,93 \\
\hline 4 & Kursk region & 65,77 & 67,51 & 75,54 & 67,89 & 70,72 & 64,22 & 68,45 & 68,70 \\
\hline 5 & $\begin{array}{l}\text { Tambov } \\
\text { Region }\end{array}$ & 55,59 & 55,43 & 55,50 & 57,03 & 56,60 & 54,36 & 56,21 & 55,86 \\
\hline 6 & $\begin{array}{l}\text { On average, } \\
\text { by constituent } \\
\text { entities of the } \\
\text { Russian } \\
\text { Federation }\end{array}$ & 58,09 & 58,95 & 59,48 & 59,71 & 57,83 & 57,70 & 58,84 & 58,66 \\
\hline
\end{tabular}

As already noted, the Voronezh region in terms of subindexes exceeds the average values for the Russian Federation, but among the regions of the Central Chernozem Region, it does not occupy high positions, lagging behind the leaders in the Belgorod and Lipetsk regions by an average of 2-3 points in almost all directions. An exception is the "Information Infrastructure" subindex, which assumes expanded implementation of federal programs in the field of interaction between automated information and analytical systems, IT corporations and university education. Ts high value (74.71) - the maximum in terms of the Central Development Center - is confirmed by the traditionally highly developed communication systems in the region. In contrast, the Voronezh region occupies particularly weak positions in the subindexes "Presence and formation of research competencies and technological groundwork" (66.17) and "Information security" (66.68). The value of the first of them reflects the insufficiently high economic activity of the region's subjects in high-tech industries. In the field of information security, priority is paid only to two areas cryptographic information protection and the use of electronic signatures [6], while the transfer of databases to domestic software is still delayed.

It is worth noting, for example, that in general, in the use of ICTs, which are the basis for the digital reorganization of the economy, the Voronezh region is the leader among neighboring regions. So, the use of ICT by ICT entities (as a percentage of the total number of organizations surveyed) in 2017 is presented in "Table III" [7].

TABLE III. THE USE OF ICT (AS A PERCENTAGE OF THE TOTAL NUMBER OF ORGANIZATIONS SURVEYED) BY SUBJECTS OF THE CENTRAL DEVELOPMENT BANK IN 2017

\begin{tabular}{|l|l|}
\hline Subject of the CDM & \multicolumn{1}{c|}{$\begin{array}{c}\text { Use of ICT in } \\
\text { organizations }\end{array}$} \\
\hline Belgorod region & 90,3 \\
\hline Voronezh region & 93,5 \\
\hline Kursk region & 82,9 \\
\hline Lipetsk region & 91,4 \\
\hline Tambov region & 89,4 \\
\hline
\end{tabular}

Nevertheless, although the indicated $93.5 \%$ of organizations use ICTs, it is possible that not all of them satisfy the previously mentioned mandatory development criteria or are deprived of proper information coverage. This situation clearly requires a detailed extended study to identify the causes of the lag and potential measures to correct it.

It is obvious that the acceleration of digital transformation processes requires joint actions not only of state and regional structures, but also representatives of business, scientific communities and innovative entrepreneurship. Such a breakthrough innovation for the Voronezh region, capable of determining regional 
- At the mesoscale:

competitiveness and ensuring economic growth, could be the formation of an IT cluster.

It should be noted that clusters in general are a good example of combining business entities into a promising network structure [8], which can fundamentally accelerate the processes of innovative development in various industries due to the intensification of the "producer consumer - state" interaction [9], [10]. The IT cluster, as a set of IT sector organizations, in turn, is called upon to develop adequate products for the domestic and foreign market in accordance with international standards.

In the process of studying world and domestic experience in using network structures in the field of IT technologies, the authors analyzed a number of successful IT clusters aimed at transferring intelligent technologies: Cyberport (Hong Kong), Kumi Electronic Industry Complex (South Korea), Small and Medium-sized Information Technology Cluster Entrepreneurship Innopolis (Tatarstan), International Cluster of Information Technologies (Nizhny Novgorod) [11, 12]. A detailed study made it possible to identify priority goals for creating IT clusters:

- development of innovative technologies for the acquisition of technological leadership;

- assistance in supporting small and medium enterprises;

- creation of a revolutionary IT infrastructure for the formation of a strategic cluster and its development

- development of training centers for IT-specialists on the basis of mutually beneficial cooperation with the leading industries of the region - industry, research institutes, government agencies and business structures;

- formation of the Internet of Things (IoT) system ("Smart Home");

- development of artificial intelligence;

- development of IT solutions to increase labor productivity.

The successful functioning of a number of IT clusters allows us to put forward a relevant hypothesis about the need for objective initial prerequisites for their formation at the macro, meso and micro levels. Taking into account domestic realities, the authors formulated a list of such premises:

- At the macro level [13]:

Coverage of the economy by globalization processes;

Creation of a single economic space on the basis of existing and newly created economic zones;

Perspective development of Internet technologies;

Increase in processing power of processors;

The ubiquity of mobile devices;

Focus on digital transformation;
Recognition of an information resource as a priority for the industry [6];

Optimization of business processes in the industry based on innovative ICT;

The emergence of new sources of industry revenue and cost reduction in the industry [6];

Availability of developed transport infrastructure;

The presence of a developed business support infrastructure;

High concentration of IT-enterprises of small and medium-sized businesses in the economic region

- At the micro level:

Recognition of the need to transform ICT-based manufacturing processes;

Adaptation of the current business model to new conditions;

The use of ICT as an effective tool to increase company productivity;

Prospective geographical location;

Enhancing corporate culture based on digital transformation.

In the appendix to the conditions of the Voronezh region, the authors highlight the following prerequisites that favor the creation of an IT cluster in the region:

- Regulation of the cluster direction of economic development is determined by a number of regulatory documents already developed at the level of the subject of the federation, namely:

The Law "On the Strategy for the Socio-Economic Development of the Voronezh Region for the Period Until 2035";

The concept of cluster policy in the industrial sector of the economy;

Government Decree "On the approval of the concept of innovation policy of the Voronezh region for 2016 - 2020".

- In the National rating of the state of the investment climate in 2018, the Voronezh region ranks seventh [5].

- At the state level, a decision was made to create, in the immediate vicinity of the existing Maslovsky industrial park, a special economic zone of the Center industrial type. A feature of the Voronezh SEZ PPT is a specialization different from neighboring similar zones - radio electronics.

- The presence in the region of territories of priority social and economic development, in particular, the 
city of Pavlovsk (government decree No. 264 of March 16, 2018) [14].

- The existing infrastructure for the development of the region - the Department of Digital Development of the Voronezh Region, State Institution "Center for Cluster Development of the Voronezh Region", the Department of Entrepreneurship and Trade, the Department of Industry and Transport, the State Fund for Small Business Support, the regional state institution "Agency for Innovation and Development of Economic and Social Projects ", Regional State Budgetary Institution" Agency for Investments and Strategic Projects ”, Industrial Development etc.

- A sufficient concentration of IT-enterprises of large and medium-sized businesses in the economic region: international operating companies - Netcracker, DataArt, DSR, Simens, Atos; federal - Mail.Ru, MTS, Reksoft, SOLVER; enterprises - distributors of software - SoftLine, 1C-Rarus; Large business IT outsourcing - MTS, Megafon, Sberbank, SIBUR,
SEVERSTAL; large state-owned companies and large businesses developing their own IT systems Rostelecom, Sberbank, etc. - including those actively using IT solutions (Voronezh Mechanical Plant, Voronezh Joint-Stock Aircraft Building Company, Sozvezdie Concern, etc.).

- The presence of developed centers for the training of IT specialists - a number of federal and autonomous non-profit educational institutions of higher education of VSTU, VSU, VSUIT, RANEPA, VIVT, etc.

Of course, the determining condition for the formation of an IT cluster on the territory of the Voronezh region and, as a consequence, the creation of a mechanism for promoting ICTs in all areas of business is the mandatory coordination of its development strategy with the general regional direction [15]. The authors believe that within the framework of the proposed IT cluster, a number of measures will be implemented to eliminate imbalances in the ratio of the levels of the individual components of the Digital Russia index in the Voronezh region ("Table IV").

TABLE IV. MEASURES TO INCREASE THE LEVEL OF DigitALIZATION IMPLEMENTED WiTHIN THE FRAMEWORK OF THE INFORMATION TECHNOLOGY CLUSTER

\begin{tabular}{|c|c|}
\hline $\begin{array}{l}\text { The main directions of the } \\
\text { implementation of regional ICT } \\
\text { initiatives }\end{array}$ & Activities ensuring the implementation of the main directions \\
\hline 1 & 2 \\
\hline Normative regulation & $\begin{array}{l}\text { - coordination of development strategies of the region and the cluster enterprises, building hierarchies of } \\
\text { specific goals in support of the agreed strategic goals of the region; } \\
\text { - development of normative legal acts on digitalization that are practical in nature, with planned financial } \\
\text { and technological results that take into account the interests of all cluster members }\end{array}$ \\
\hline $\begin{array}{l}\text { Specialized personnel and training } \\
\text { programs }\end{array}$ & $\begin{array}{l}\text { - inclusion in the cluster of institutions of secondary and secondary education, the formation of networks of } \\
\text { quantoriums; } \\
\text { - creation of conditions for training and further training of specialists in the field of robotics, the Internet of } \\
\text { things and other innovative technologies necessary for enterprises participating in the cluster; } \\
\text { - the formation of a stably functioning system of international cooperation in the field of innovative } \\
\text { scientific and technological development of countries, including in the field of digital economy; } \\
\text { - holding forums, conferences, seminars on innovative topics, including such as blockchain, } \\
\text { cryptocurrencies, big data, AR / VR and other cross-cutting technologies of the digital economy }\end{array}$ \\
\hline $\begin{array}{lrr}\begin{array}{l}\text { Formation } \\
\text { competencies } \\
\text { groundwork }\end{array} & \text { and } & \text { research } \\
\text { technological }\end{array}$ & $\begin{array}{l}\text { - public-private partnership and co-financing of research and development in the field of artificial } \\
\text { intelligence, robotics, nanotechnology, digitalization of the agro-industrial complex and the oil industry; } \\
\text { promoting the commercialization of research results }\end{array}$ \\
\hline $\begin{array}{l}\text { Formation of the information } \\
\text { infrastructure }\end{array}$ & $\begin{array}{l}\text { - participation of cluster enterprises in the implementation of programs for the transition to electronic } \\
\text { exchange of documents (information) in the provision of public services, automation of a number of } \\
\text { government procedures and processes, use of an automated decision support system; } \\
\text { - creation of new digital infrastructure solutions based on distributed registries; } \\
\text { - participation in the Smart City program }\end{array}$ \\
\hline $\begin{array}{l}\text { Creation of an information security } \\
\text { system }\end{array}$ & $\begin{array}{l}\text { - participation in projects to create an internal Russian infrastructure designed to ensure the independence } \\
\text { of the Russian Internet cluster from foreign Internet nodes at the server level and at the DNS level; } \\
\text { - transfer of electronic document management systems to domestic software }\end{array}$ \\
\hline \multicolumn{2}{|r|}{ Continuation of "Table IV" } \\
\hline 1 & 2 \\
\hline $\begin{array}{l}\text { Getting the economic and social } \\
\text { effect of digitalization }\end{array}$ & $\begin{array}{l}\text { - development of IT projects for large businesses; } \\
\text { - Creation of joint platforms for cross-border cooperation; } \\
\text { - formation of the infrastructure for collective development of software for the implementation of digital } \\
\text { economy technologies, participation in the work of centers for the collective use of digital equipment; } \\
\text { - development of projects for the interaction of citizens with local authorities through local digital } \\
\text { communication channels; } \\
\text { - development and implementation of advanced information technologies in healthcare; } \\
\text { - assistance in expanding access to the Internet, including free, in public places }\end{array}$ \\
\hline
\end{tabular}


condition for increasing the competitiveness of a region / T. S. Narolina, B. G. Preobrazhensky // REGION: systems, economics, management. - 2008. - No. 1 (1). - S. 139-144.

Thus, the analysis of the results of assessing the digitalization level of the regions of the Central Black Earth Region has revealed a number of problematic issues in the field of ICT implementation in different subjects of the federation. A study of the values of the Digital Russia subindexes determined the main directions for implementing initiatives to overcome the lag of the Voronezh region from its neighbors in the Central Chernozem Region, and a study of potential goals and conditions for the formation of network structures in the region allows us to conclude that there are positive prospects for creating an IT cluster.

\section{REFERENCES}

[1] Strategies for the development of the information society of the Russian Federation for 2017-2030: Decree of the President of the Russian Federation of 05.09.2017 No. 203. Access mode: https://www.garant.ru/products/ipo/prime/doc/71570570/

[2] Talantsev V.I., Ravnyansky A.K. Digital economy and its role in the development of small and medium innovative entrepreneurship in Russia / V.I. Talantsev, A.K. Ravnyansky // Regional problems of economic transformation. - 2018.- No. 2 (88). - S. 80-86.

[3] Digital Russia Index. Access Mode: https://finance.skolkovo.ru /downloads/documents/FinChair/Research_Reports/SKOLKOVO_Di gital_Russia_Report_Full_2019-04_en.pdf

[4] I. Beinar, T. Narolina. Assessing the level of innovative attractiveness of a region based on the model of innovation activity dynamics / I. Beinar, T. S. Narolina // REGION: systems, economics, management. - 2018 .-- No. 2 (41). - S. 112-122.

[5] National rating of the state of the investment climate in 2018 https://asi.ru/news/91678/

[6] Beynar I. A. Economic support of information security of the organization / I. A. Beynar // Competitiveness. Innovation Finance. 2011. - No. 2. - S. 70-75.

[7] Regions of Russia. Socio-economic indicators. 2018. Access mode: http://www.gks.ru/bgd/regl/b18_14p/Main.htm

[8] Kurkina E.S., Knyazeva E.N. Network revolution / E. S. Kurkina, E. N. Knyazev // Economic strategies. - 2017. - No. 5. - S. 128 -137.

[9] Myasnyankina O.V. Problems of regional industrial development / O.V. Myasnyankina // REGION: systems, economics, management. 2010. - No. 3 (10). - S. 26-28.

[10] Narolina TS, Akulinin S.A. Creation of regional clusters as a means of increasing the competitiveness of regional enterprises / T. S. Narolina, S. A. Akulinin // Interuniversity collection of scientific papers. Advanced technologies and equipment in electronics and mechanical engineering. Voronezh State Technical University. Voronezh, - 2005 .-- S. 137-142.

[11] Kireeva A.A. Identification of promising areas for the formation of IT clusters in the regions of Kazakhstan: methodological approaches and their testing / A. A. Kireeva // Problems of the development of the territory. - 2017. - No. 2 (88). - S. 207-223.

[12] Myasnyankina OV Cluster policy in improving the competitiveness of the regional economy / O.V. Myasnyankina // REGION: systems, economics, management. - 2009. - No. 3 (6). - S. 72-77.

[13] Khalin V.G., Chernova G.V. Digitalization and its impact on the Russian economy and society: advantages, challenges, threats and risks / V. G. Khalin, G. V. Chernova // Management Consulting. 2018. - No. 10. - P.40-63.

[14] Decree of the Government of the Russian Federation of March 16, 2018 No. 264 "On the creation of the territory of the advanced social and economic development of Pavlovsk". Access Mode: https://www.garant.ru/products/ipo/prime/doc/71801078/ [15] Narolina TS, Preobrazhensky B.G. Effective management as a
[15] Narolina TS, Preobrazhensky B.G. Effective management as a condition for increasing the competitiveness of a region / T. S. Narolina, B. G. Preobrazhensky // REGION: systems, economics, management. - 2008. - No. 1 (1). - S. 139-144. 